\title{
PREVALENCE AND RISK FACTORS FOR INTESTINAL PROTOZOA INFECTION IN ELDERLY RESIDENTS AT LONG TERM RESIDENCY INSTITUTIONS IN SOUTHEASTERN BRAZIL
}

Katymilla Guimarães GIROTTO(1), Daliane Faria GRAMA(1), Maria Júlia Rodrigues da CUNHA(1), Elaine Silva Marques FARIA(1), Jean Ezequiel LIMONGI(2), Rogério de Melo Costa PINTO(3) \& Márcia Cristina CURY(1)

\begin{abstract}
SUMMARY
This study determined the prevalence of intestinal protozoa in Long Term Residency Institutions for the Elderly (ILPI) in elders, nurses and food handlers, identifying the risk factors associated with the infections. Stool samples taken from the elderly $(\mathrm{n}=293$ ), nurses (63) and food handlers (19) were studied. Questionnaires were used with questions related to sociodemographic variables, health, behavior and health characteristics. Stool samples were examined using the techniques of Faust and Ziehl Neelsen, and the prevalence of $G$. duodenalis, Cryptosporidium spp., E. histolytica/dispar in the elderly was $4.0 \%, 1.0 \%$ and $0.3 \%$ respectively. Nurses and food handlers showed $4.8 \%$ and $5.2 \%$ positivity only for G. duodenalis, respectively. The origin of the individuals and contact with domestic animals has been associated with infection by G. duodenalis in the elderly, and contact with domestic animals was considered a risk factor for infection. The last stool examinations were related to Cryptosporidium spp.. None of the variables were associated with $E$. histolytica/dispar. The frequency of hand washing was significantly associated with $G$. duodenalis among nurses. The frequency of positive samples of G. duodenalis, Cryptosporidium spp., E. histolytica/dispar showed that ILPIs environments are conducive to this occurring due to contact between the elderly, nurses and food handlers, which are often poorly trained in hygiene procedures and food handling.
\end{abstract}

KEYWORDS: Elderly; Intestinal protozoa; Risk factors.

\section{INTRODUCTION}

Enteric parasitosis in the elderly can acquire a serious nature due to the ageing of the immune system leading to morphophysiological changes in these individuals ${ }^{8,28}$.

The intestinal protozoa G. duodenalis, Cryptosporidium spp. and E.histolytica/dispar are important for the elderly because they are borne in water and food and are associated with unreliable hygiene habits. $G$. duodenalis and Cryptosporidium spp. are also important in public health due to their zoonotic potential ${ }^{25}$. The prevalence of these protozoa is related to human clusters, therefore, nursing homes became important sites for the research of these organisms ${ }^{6}$.

Despite the ageing of the world's population and the presence of these protozoa in several localities, there are few reports on their prevalence and epidemiological aspects in the elderly population. Therefore studies are needed to improve the quality of life of this section of the human population. This study determined the prevalence of intestinal protozoa in elderly residents and workers at Long Term Residency Institutions for the Elderly (ILPI), investigating the risk factors for infection in these individuals.

\section{MATERIAL AND METHODS}

This study was characterized as sectional and was conducted between December 2009 and October 2010 in the 16 ILPI in the municipalities of Araguari, Monte Alegre de Minas, Tupaciguara and Uberlândia, in the State of Minas Gerais, Brazil.

The population studied composed of 293 elderly residents in those ILPIs of both genders, with an age range of between 60 and 106 years old. 63 nurses and 19 food handlers from the same institutions were also evaluated.

Stool samples were collected and stored in identified collector flasks. These flasks were transported to the Parasitology Laboratory of the Federal University of Uberlândia (UFU), stored under refrigeration at $4{ }^{\circ} \mathrm{C}$ and processed within 24 hours of the collection time. Due to the intermittent pattern of $G$. duodenalis and to increase the reliability of the results, three stool samples were collected from each individual on alternate days ${ }^{5}$.

Each sample was divided in two, and the first portion was used in

(1) Instituto de Ciências Biomédicas, Laboratório de Parasitologia, Universidade Federal de Uberlândia, Minas Gerais, Brazil.

(2) Instituto de Ciências Biomédicas, Laboratório de Biologia Molecular, Universidade Federal de Uberlândia, Minas Gerais, Brazil.

(3) Faculdade de Matemática, Universidade Federal de Uberlândia, Minas Gerais, Brazil.

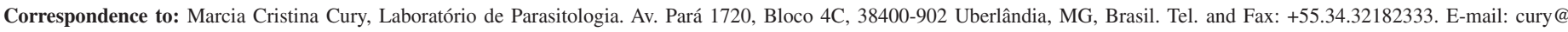
umuarama.ufu.br 
GIROTTO, K.G.; GRAMA, D.F.; CUNHA, M.J.R.; FARIA, E.S.M.; LIMONGI, J.E.; PINTO, R.M.C. \& CURY, M.C. - Prevalence and risk factors for intestinal protozoa infection in elderly residents at Long Term Residency Institutions in Southeastern Brazil. Rev. Inst. Med. Trop. Sao Paulo, 55(1): 19-24, 2013.

the search for G. duodenalis and E.histolytica/dispar cysts using 33\% of Zinc Sulfate Centrifugal Flotation in the Method ${ }^{10}$, performed with fresh feces. In the second portion the three samplings were pooled together and preserved in $10 \%$ formalin, they were used in the search for Cryptosporidium spp. oocysts by examining the concentration in formalin ether ${ }^{22}$ and Ziehl Neelsen staining ${ }^{13}$. Three slides were made per individual and examined by two trained professionals.

Four questionnaires were prepared, one related to the ILPI; another for the elderly; the third for the nurses and the fourth for the food handlers.

The data were analyzed by EPI INFO 3.3.2 software (CDC, Atlanta, GA, USA). The Chi-square test $\left(\mathrm{X}^{2}, \alpha=5 \%\right)$ was used in the comparison of two proportions. The ANOVA test was used for the comparison between the groups and the variables in which the average of the results were used. The Mann-Whitney test was used when the data did not present a normal distribution. The odds ratio (OR) with a confidence interval (CI) of $95 \%^{16}$ was used to evaluate the possible risk factors associated with infection of the intestinal protozoa. At frequencies lower than five, the statistical significance was calculated using simulation by the Monte Carlo method with 2,000 samplings being studied ${ }^{29}$.
The study was approved by the Ethical Research Committee - CEP, under the CEP/UFU: 031/10 Protocol.

\section{RESULTS}

Out of the total number of samples taken from the elderly, $28(9.5 \%)$ tested positive for intestinal protozoa, distributed as $10(35.7 \%)$ for $G$. duodenalis, three (10.7\%) for Cryptosporidium spp., nine (32.2\%) for Entamoeba coli and two (7.1\%) for Endolimax nana. Four of the elders (14.3\%) presented bi-parasitism, with two $(50.0 \%)$ being positive for G. duodenalis and E. coli; one (25.0\%) for E. nana and E.coli and one (25.0\%) for E.histolytica/dispar and E. coli.

Regarding the positivity of $G$. duodenalis $(\mathrm{n}=12)$ among the sociodemographic, hygienic and behavioral variables (Table 1), the origin $(\mathrm{OR}=1.70(0.30-7.75) ; \mathrm{p}=0.03)$ and contact with domestic animals, all were statistically significant with exception of the last which was considered a risk factor for infection $(\mathrm{OR}=15.34$ (1.66-114.32); $p=0.02$ ). The other variables related to health care had no relationship with this protozoon.

Table 1

Sociodemographic, hygienic and behavioral profile of 293 elderly, positive and negative for Giardia duodenalis and residents in 16 ILPI from the municipalities of Araguari, Monte Alegre de Minas, Tupaciguara and Uberlândia surveyed from December 2009 to October 2010

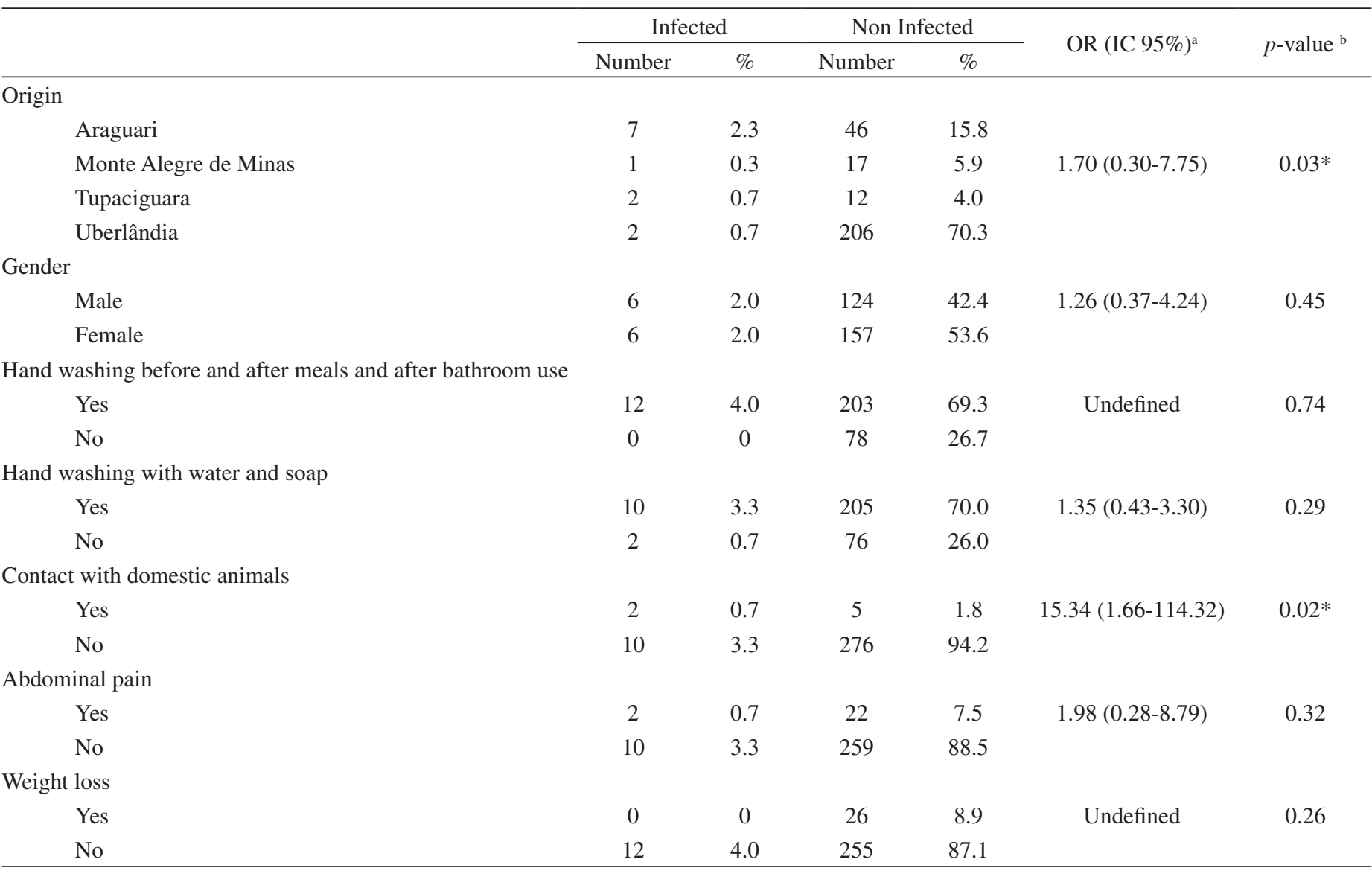

$\overline{\mathrm{a}}=$ OR Odds Ratio; IC, Confidence Interval; $\mathrm{b}=$ Fisher Exact Test, Chi-square Test, ANOVA, Chi-square Test with Monte Carlo simulation or logistic regression * $p \leq 0.05$. 


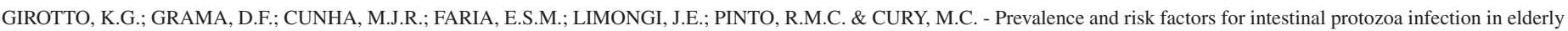
residents at Long Term Residency Institutions in Southeastern Brazil. Rev. Inst. Med. Trop. Sao Paulo, 55(1): 19-24, 2013.

Table 2

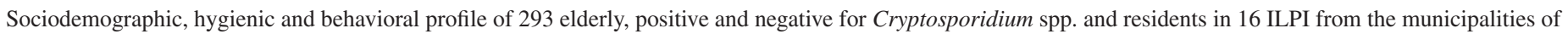
Araguari, Monte Alegre de Minas, Tupaciguara and Uberlândia surveyed from December 2009 to October 2010

\begin{tabular}{|c|c|c|c|c|c|c|}
\hline \multirow{2}{*}{ Variables } & \multicolumn{2}{|c|}{ Infected } & \multicolumn{2}{|c|}{ Non Infected } & \multirow{2}{*}{ OR $(\operatorname{IC~} 95 \%)^{a}$} & \multirow{2}{*}{$p$-value ${ }^{\mathrm{b}}$} \\
\hline & Number & $\%$ & Number & $\%$ & & \\
\hline \multicolumn{7}{|l|}{ Origin } \\
\hline Araguari & 0 & 0 & 53 & 18.1 & & \\
\hline Monte Alegre de Minas & 0 & 0 & 17 & 5.8 & Undefined & 0.75 \\
\hline Tupaciguara & 0 & 0 & 12 & 4.1 & & \\
\hline Uberlândia & 3 & 1.0 & 208 & 71.0 & & \\
\hline \multicolumn{7}{|l|}{ Gender } \\
\hline Male & 2 & 0.7 & 128 & 43.7 & $2.52(0.19-75.09)$ & 0.41 \\
\hline Female & 1 & 0.3 & 162 & 55.3 & & \\
\hline \multicolumn{7}{|c|}{ Hand washing before and after meals and after bathroom use } \\
\hline Yes & 3 & 1.0 & 171 & 58.4 & Undefined & 0.99 \\
\hline No & 0 & 0 & 119 & 40.6 & & \\
\hline \multicolumn{7}{|l|}{ Hand washing with water and soap } \\
\hline Yes & 2 & 0.7 & 276 & 94.2 & $3.35(0.22-88.03)$ & 0.18 \\
\hline No & 1 & 0.3 & 14 & 4.8 & & \\
\hline \multicolumn{7}{|l|}{ Contact with domestic animals } \\
\hline Yes & 1 & 0.3 & 3 & 1.0 & $23.14(0.69-349.6)$ & 0.07 \\
\hline No & 2 & 0.7 & 287 & 98.0 & & \\
\hline \multicolumn{7}{|l|}{ Feces examination } \\
\hline Yes & 3 & 1.0 & 268 & 91.5 & Undefined & 0.76 \\
\hline No & 0 & 0 & 22 & 7.5 & & \\
\hline \multicolumn{7}{|l|}{ Time of feces examination } \\
\hline More than one year & 1 & 0.4 & 240 & 88.5 & & \\
\hline Between six months and one year & 2 & 0.7 & 8 & 3.0 & Undefined & $0.04 *$ \\
\hline Less than six months & 0 & 0 & 12 & 4.4 & & \\
\hline Unknown & 0 & 0 & 8 & 3.0 & & \\
\hline \multicolumn{7}{|l|}{ Abdominal pain } \\
\hline Yes & 1 & 0.3 & 22 & 7.5 & $4.65(0.15-63.1)$ & 0.76 \\
\hline No & 2 & 0.7 & 268 & 91.5 & & \\
\hline \multicolumn{7}{|l|}{ Weight loss } \\
\hline Yes & 1 & 0.3 & 26 & 8.9 & $4.26(0.14-57.72)$ & 0.28 \\
\hline No & 2 & 0.7 & 264 & 90.1 & & \\
\hline
\end{tabular}

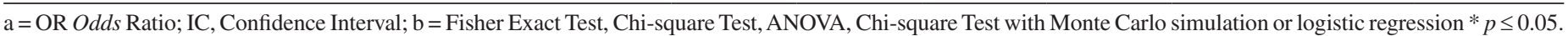

Three elders (1.0\%) presented single parasitism with Cryptosporidium spp.. Among the analyzed variables, only the time of completion of the last coproparasitological examination was statistically significant ( $p=$ 0.04) (Table 2).

Only one elderly presented positivity for E.histolytica/dispar, however without symptoms. The analyzed variables were not significant $(p>0.05)$.

Three nurses (4.8\%) were tested positive for G. duodenalis and sociodemographic, behavior and associated factors with elderly health care, were not significant $(p>0.05)$. The frequency of hand washing during the day, about $36.66 \pm 5.77$ times $(p=0.02)$, was the only variable related to hygiene that presented statistical significance with undefined odds ratio (OR) (Table 3).

One (5.2\%) out of the 19 food handlers presented parasitism for $G$. duodenalis. No statistically significant difference among the analyzed variables was observed $(p>0.05)$.

\section{DISCUSSION}

The prevalence of $G$. duodenalis in the elderly was higher than observed in previous studies ${ }^{1,2,3,20,23}$ and lower than observed in other studies ${ }^{12,14,27}$. The difference in the results can be associated with the number of samples taken, methodology, environmental differences and 


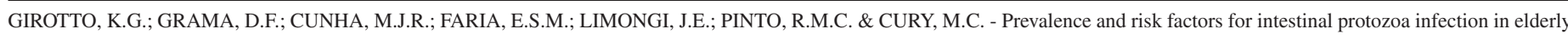
residents at Long Term Residency Institutions in Southeastern Brazil. Rev. Inst. Med. Trop. Sao Paulo, 55(1): 19-24, 2013.

Table 3

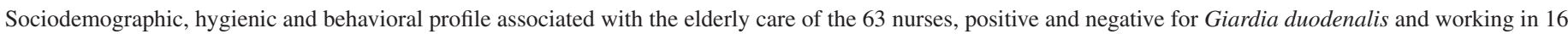
ILPI from the municipalities of Araguari, Monte Alegre de Minas, Tupaciguara and Uberlândia surveyed from December 2009 to October 2010

\begin{tabular}{llllll}
\hline \multirow{2}{*}{ Variables } & \multicolumn{2}{c}{ Infected } & Non Infected $^{*}$ & OR (IC 95\%) & \\
\cline { 2 - 4 } & $\mathrm{N}^{\circ}$ & $\%$-value & \\
\hline
\end{tabular}

Origin

Araguari

Monte Alegre de Minas

Tupaciguara

Uberlândia

Gender

Male

Female

Frequency of daily hand washing

Up to ten times

Between 10 and 20 times

Between 21 and 30 times

More than 31 times

Hand washing before and after meals and after bathroom use

Yes

No

Hand washing before and after caring for the elderly

Yes

No

Contact with domestic animals

Yes

No

2

1

Abdominal pain

Yes

No

Weight loss

Yes

No

0

0

0

3

1

2

\section{0}

0

1

2

$$
3
$$

0

3

0

1

2

$$
4.8
$$

0

$$
4.8
$$

0

1.6

3.2

0

0

1.6

3.2

4
3
2
51

4

3

2

6.3

4.8

3.2

80.9

4.8

5

55

7.9

87.3

15.9

44.4

28.6

6.3

10
28
18
4

90.4

4.8

3

59

93.6

1.6

3.2

29

46.0

49.2

$\begin{array}{ll}1.6 & 14 \\ 3.2 & 46\end{array}$
22.2
73.0

$1.62(0.05-22.78)$

22.2

$5.24(0.15-79.95)$

$2.11(0.15-64.96)$

1.6

$\begin{array}{ll}14 & 22.2 \\ 46 & 73.0\end{array}$

3.2

$\overline{\mathrm{a}}=$ OR Odds Ratio; IC, Confidence Interval; $\mathrm{b}=$ Fisher Exact Test, Chi-square Test, ANOVA, Chi-square Test with Monte Carlo simulation or logistic regression * $p \leq 0.05$.

host immunological conditions. Researchers claim that there is a lower risk of G. duodenalis infection with the advancement of age due to cellular and humoral immune responses that would protect these individuals from re-infection ${ }^{15,19}$.

The prevalence observed for Cryptosporidium spp. in the elderly was lower than the ones presented on research ${ }^{7,21,24}$. Factors affecting the survival and the number of oocysts present in the environment, such as rain or agricultural practices, can interfere with differences in the prevalence of that protozoan. The prevalence of intestinal protozoa is associated with the combination of multiple variables that determine the interaction between the parasite, the host and the environment ${ }^{18}$. In addition, the migration of people and the presence of animals as reservoirs, linked to poor sanitary conditions, are factors that contribute to contamination through drinking water which is the main route of transmission of this protozoan ${ }^{24}$.
The prevalence of E.histolytica/dispar was lower than the previous ones mentioned ${ }^{2,3,23,24}$. This protozoan is common in inhabitants of developing countries, affecting predominantly people living with precarious socioeconomic conditions, inadequate hygiene practices and malnutrition ${ }^{24}$. The prevalence of this parasite is influenced by local agglomeration, inadequate supply of water, quality of consumed water, lack of basic sanitation, bathroom habits, lack of adequate urban services, age, ingestion of raw vegetables, number of bedrooms and bathrooms per house and the presence of other intestinal protozoa ${ }^{4}$.

In this study, as well as in others ${ }^{14,23}$, gender and age were not important variables; however, some authors mention gender as a factor associated to giardiasis ${ }^{27}$. Age did not present any correlation with the presence of Cryptosporidium spp., but is an important factor ${ }^{7,21}$. The elderly are more susceptible to having serious illnesses with age advancement, and these diseases can present longer duration thereby 


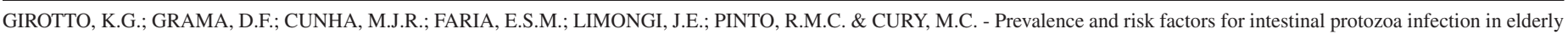
residents at Long Term Residency Institutions in Southeastern Brazil. Rev. Inst. Med. Trop. Sao Paulo, 55(1): 19-24, 2013.

increasing the chance that individuals may have higher rates of secondary infections, such as enteroparasitosis ${ }^{9}$

The origin of the institution where the elderly lived was important only when associated with $G$. duodenalis, and there is no basis of explanation for this association. Nevertheless, the water quality and the level of basic sanitation in the municipality are highlighted as having the potential to influence the quality of life and health of the local population.

Good personal hygiene habits are fundamental for reducing the transmissibility of pathogens. Poor hygiene behavior, contaminated hands, food and water can spread pathogens ${ }^{11}$.

Contact with domestic animals increased the risk of the elderly acquiring $G$. duodenalis by 15.34 times. The transmission of this protozoan can occur from person to person through food, the environment (mainly by direct contact with contaminated soil and water) or contact with animals. The understanding of Giardia transmission from dogs and other animals to humans and vice versa depends on more biological, molecular and epidemiological studies ${ }^{17}$.

The time of the last coproparasitological examination proved to be an important variable in the presence of Cryptosporidium spp. infection. For some authors, despite the clinical examination being the first step in the diagnosis of protozoa infection, the parasitological examination is essential for establishing the presence of the parasite in the individual ${ }^{3}$.

The $4.8 \%$ prevalence of infection rate was observed among the nurses who cared for the elderly in this study. As they are the professionals responsible for the hygiene and medication of the institutionalized elderly, they can be a source of infection for those elders. Direct person-to-person transmission occurs mainly in closed communities, such as children's day care centers, orphanages and nurseries ${ }^{26}$.

The association between the frequency of hand washing and the positivity of $G$. duodenalis in the health professionals was observed in this study. It is expected that higher frequency in hand washing decreases the likelihood of the presence of pathogens. However, factors such as water quality and the procedure used in hand washing can be critical in determining the presence of intestinal protozoan cysts and thus, leading to the contamination of these professionals.

The presence of G. duodenalis among the food handlers is important because one positive individual can be the source of contamination to others. The food handlers are responsible for ensuring that the food remains healthy throughout its preparation process ${ }^{16}$. Approximately 10 to $20 \%$ of food-borne disease outbreaks are resultant from contamination by food handlers ${ }^{30}$.

The positivity for G. duodenalis, Cryptosporidium spp. and E.histolytica/dispar demonstrate that ILPI are supportive environments to the occurrence of these infections due to contact between the elderly, nurses/nursing, technicians/caregivers and food handlers.

\section{CONFLICT OF INTEREST}

\section{RESUMO}

\section{Prevalência e fatores de risco para infecção por protozoários intestinais em idosos residentes nas Instituições de Longa Permanência no Sudeste do Brasil}

Este estudo determinou a prevalência de protozoários intestinais em Instituições de Longa Permanência para Idosos (ILPI), enfermeiros, manipuladores de alimentos identificando fatores de risco associados às infecções. Amostras de fezes de idosos $(n=293)$, enfermeiros $(63)$, manipuladores de alimentos (19) foram estudadas. Foram aplicados questionários relacionados a variáveis sociodemográficas, de higiene, comportamento e características de saúde. As amostras de fezes foram examinadas pelas técnicas de Faust e Ziehl Neelsen e a prevalência de G. duodenalis, Cryptosporidium spp., E.histolytica/dispar nos idosos foi de 4,0\%, 1,0\% e 0,3\%, respectivamente. Enfermeiros e manipuladores de alimentos apresentaram 4,8\% e 5,2\% de positividade apenas para $G$. duodenalis, respectivamente. A origem dos indivíduos, o contato com animais domésticos foram associados à infecção por $G$. duodenalis nos idosos, sendo que o contato com animais domésticos foi considerado um fator de risco para a infecção, o tempo do último exame coproparasitológico foi relacionado a Cryptosporidium spp.. Nenhuma das variáveis apresentaram associação com E. histolytica/dispar. A frequência da lavagem das mãos foi associada significativamente com $G$. duodenalis entre enfermeiros. As frequências de amostras positivas para G. duodenalis, Cryptosporidium spp., E. histolytica/dispar demonstram que ILPIs são ambientes propícios para esta ocorrência devido ao contato entre idosos, enfermeiros, manipuladores de alimentos, que muitas vezes são mal treinados em procedimentos de higiene e manipulação de alimentos.

\section{ACKNOWLEDGEMENTS}

We are thankful to the directors, coordinators, staff and elders at the Long Term Residency Institutions for collaborating with the execution of this study.

\section{FINANCIAL SUPPORT}

We are thankful to the Coordenação de Aperfeiçoamento de Pessoal de Nível Superior (CAPES) for their financial support.

\section{REFERENCES}

1. Araj GF, Musharrafieh UM, Haydar A, Ghawi A, Itani R, Saliba R. Trends and prevalence of intestinal parasites at a tertiary care center in Lebanon over a decade. J Med Liban. 2011;59:143-8.

2. Araújo CFF, Correia JS. Frequência de parasitoses intestinais em idosos dos núcleos da prefeitura de João Pessoa, Estado da Paraíba. Rev Bras Anál Clín. 1997;29:230-1.

3. Araújo CF, Fernández CL. Prevalência de parasitoses intestinais na cidade de Eirunepé, Amazonas. Rev Soc Bras Med Trop. 2005;38:69.

4. Benetton MLFN, Gonçalves AV, Meneghini MEF, Silva EF, Carneiro M. Risk factors for infection by the Entamoeba histolytica/E.dispar complex; an epidemiological study conducted in outpatient clinics in the city of Manaus, Amazon Region, Brazil Trans R Soc Trop Med Hyg. 2005;99:532-40.

Not declared. 
GIROTTO, K.G.; GRAMA, D.F.; CUNHA, M.J.R.; FARIA, E.S.M.; LIMONGI, J.E.; PINTO, R.M.C. \& CURY, M.C. - Prevalence and risk factors for intestinal protozoa infection in elderly residents at Long Term Residency Institutions in Southeastern Brazil. Rev. Inst. Med. Trop. Sao Paulo, 55(1): 19-24, 2013.

5. Carvalho TB, Carvalho LR, Mascarini LM. Ocurrence of enteroparasites in day care centers in Botucatu (São Paulo State, Brazil) with emphasis on Crypstosporidium sp., G. duodenalis and Enterobius vermiculares. Rev Inst Med Trop Sao Paulo. 2006;48:269-73

6. Carvalho TTR. Estado atual do conhecimento de Cryptosporidium e Giardia. Rev Patol Trop. 2009;38:1-16

7. Chai JY, Kim NY, Guk SM, Park YK, Seo M, Han ET, et al. High prevalence and seasonality of cryptosporidiosis in a small rural village occupied predominantly by aged people in the Republic of Korea. Am J Trop Med Hyg. 2001;65:518-22.

8. Effros RB. Genetic alterations in the ageing immune system: impact on infection and cancer. Mech Ageing Dev. 2003;124:71-7.

9. Elsenberg JNS, Lei X, Hubbard AH, Brookhart MA, Colford JM Jr. The role of disease transmission and conferred immunity in outbreaks: analysis of the 1993 Cryptosporidium outbreak in Milwaukee, Wisconsin. Am J Epidemiol. 2005;161:6272.

10. Faust EC, Sawitz W, Tobie J, Odom V, Peres C, Lincicome DR. Comparative efficiency of various technics for the diagnosis of protozoan and helminths in feces. J Parasitol. $1939 ; 25: 241-62$.

11. Fewtrell L, Kaufmann RB, Kay D, Enanoria W, Haller L, Colford JM Jr. Water, sanitation, and hygiene interventions to reduce diarrhoea in less developed countries: a systematic review and meta-analysis. Lancet Infect Dis. 2005;5:42-52.

12. Furtado LF, Melo AC. Prevalência e aspectos epidemiológicos de enteroparasitoses na população geronte de Parnaíba, Estado do Piauí. Rev Soc Bras Med Trop. 2011;44:513-5

13. Henriksen SA, Pohlenz JFL. Staining of cryptosporidia by a modified Ziehl-Neelsen technique. Acta Vet Scand. 1981;22:594-6.

14. Hurtado-Guerreiro AF, Alencar FH, Hurtado-Guerreiro JC. Ocorrência de enteroparasitas na população geronte de Nova Olinda do Norte-Amazonas, Brasil. Acta Amazônica. 2005;35:487-90.

15. Laupland KB, Church DL. Population-based laboratory surveillance for Giardia sp. and Cryptosporidium sp. infections in a large Canadian health region. BMC Infect Dis. $2005 ; 16: 5-72$.

16. Mohammed Mahdy AK, Lim YA, Surin J, Wan KL, Al-Mekhlafi MS. Risk factors for endemic giardiasis: highlighting the possible association of contaminated water and food. Trans R Soc Trop Med Hyg. 2008;102:465-70.

17. Monis PT, Thompson RCA. Cryptosporidium and Giardia-zoonoses: fact or fiction? Infect Genet Evol. 2003;3:233-44.
18. Moraes Neto AH, Pereira AP, Alencar MFL, Souza-Júnior PRB, Dias RC, Fonseca JG, et al. Prevalence of intestinal parasites versus knowledge, attitudes, and practices of inhabitants of low-income communities of Campos dos Goytacazes, Rio de Janeiro State, Brazil. Parasitol Res. 2010;107:295-307.

19. Oda Y, Sherchand JB. Study of the prevalence of parasitic infection among students in Kathmandu related to drinking water. J Nepal Ass Med Lab Sci. 2002;4:36-41.

20. Oliveira MR, Barbosa MA, Salata E, Sogayar MITL, Sogayar R, Corrêa FMA. Prevalência de enteroparasitas na população urbana do $2^{\circ}$ distrito de Botucatu. Rev Saúde Pública. 1974;8:213-34

21. Park JH, Kim HJ, Guk SM, Shin EH, Kim JL, Rim HJ, et al. A survey of cryptosporidiosis among 2,541 residents of 25 coastal islands in Jeollanam-Do (Province), Republic of Korea. Korean J Parasitol. 2006;44:367-72.

22. Ritchie LS. An ether sedimentation technique for routine stool examinations. Bull U S Army Med Dep. 1948;8:326

23. Santos SA, Merlini LS. Prevalência de enteroparasitoses na população do município de Maria Helena, Paraná. Ciên Saúde Colet. 2010;15:899-905.

24. Shakya B, Rai SK, Singh A, Shresta A. Intestinal parasitosis among the elderly people in Kathmandu Valley. Nepal Med Coll J. 2006;8:243-7.

25. Thompson RCA. Giardiasis as a re-emerging infectious disease and its zoonotic potential. Int J Parasitol. 2000;30:1259-67.

26. Torres DM, Chieffi PP, Costa WA, Kudzielics E. Giardíase em creches mantidas pela Prefeitura do Município de São Paulo, 1982/1983. Rev Inst Med Trop Sao Paulo. $1991 ; 33: 137-42$

27. Wensaas K-A, Langeland N, Rortveit G. Prevalence of recurring symptoms afte infection with Giardia lamblia in a non-endemic area. Scand J Prim Health Care. $2009 \cdot 27: 12-7$

28. Wu D, Meydani SN. Age-associated changes in immune and inflammatory responses. J Leukocyte Biol. 2008;84:1-15

29. www.R-project.org. The R project for statistical computing. [cited 2010 Nov 20] Available from: http://www.R-project.org

30. Zain MM, Naing NN. Sociodemographic characteristics of food handlers and their knowledge, attitude and practice towards food sanitation: a preliminary report. Southeast Asian J Trop Med Public Health. 2002;33:410-7.

Received: 13 April 2012

Accepted: 18 July 2012 